\title{
Evaluation of lead exposure in workers at a lead- acid battery factory in Korea: with focus on activity of erythrocyte pyrimidine 5'-nucleotidase (P5N)
}

Yangho Kim, Koichi Harada, Shoko Ohmori, Byung-Kook Lee, Hajime Miura, Atsushi Ueda

\begin{abstract}
Objective-To evaluate lead exposure among lead-acid battery workers in Korea, to evaluate in more detail the erythrocyte pyrimidine $5^{\prime}$-nucleotidase (P5N) test for lead exposure, and to evaluate the abnormal accumulation of erythrocyte pyrimidine nucleotides in the battery workers.
\end{abstract}

Methods-Activity of P5N and other biological variables were examined in 66 exposed workers in a lead-acid battery factory and in 26 non-exposed workers in Korea.

Results-At the factory the timeweighted average of $13(72 \%)$ of 18 air samples for lead exceeded 0.05 (range $0.012-0.468) \mathrm{mg} / \mathrm{m}^{3}$. Blood lead concentration (PbB) in 39 of the 66 exposed workers was above $40 \mu \mathrm{g} / \mathrm{dl}$, and the mean (SD) $\mathrm{PbB}$ in the exposed group was 45.7 $(15 \cdot 7) \mu g / d 1$. Compared with the nonexposed group, free erythrocyte protoporphyrin in the exposed group was significantly increased, whereas erythrocyte P5N activity and activity of erythrocyte $\delta$-aminolevulinic acid dehydratase (ALAD) were significantly inhibited. Erythrocyte P5N activity had valid correlation biologically with $\mathrm{PbB}$ and with other biological variables, such as ALAD activity. In 28 exposed workers, the concentration of erythrocyte pyrimidine nucleotides (uridine 5'-diphosphateglucose and cytidine 5'-triphosphate) correlated inversely with $\mathrm{P} 5 \mathrm{~N}$ activity and positively with $\mathrm{PbB}$.

Conclusions-These findings show that the depression of erythrocyte P5N activity by lead exposure results in the accumulation of erythrocyte pyrimidine nucleotides. In general, the standard analysis of $\mathbf{P b B}$ performed in laboratories around the world remains the most useful index of recent exposure. The results indicate that the erythrocyte P5N activity test provides supporting evidence of lead exposure and shows the effect of lead on nucleotide metabolism.

(Occup Environ Med 1995;52:484-488)

Keywords: erythrocyte pyrimidine 5'-nucleotidase (P5N); lead; nucleotide metabolism

Although the toxic effects of exposure to lead are well known, occupational lead poisoning continues to occur worldwide. In the leadacid battery industry, one of the largest users of lead, workers are at high risk of lead toxicity. ${ }^{1}$ Although this risk has been thoroughly studied and controlled in most developed countries, in developing countries significant exposure to lead among lead-acid battery workers is still common. ${ }^{23}$

Erythrocyte pyrimidine 5'-nucleotidase (P5N), which catalyses the hydrolytic dephosphorylation of pyrimidine 5'-monophosphates, is inhibited by lead, and its activity is considered to be an indicator of lead exposure. ${ }^{4}$ Also, it has been reported that the depression of $\mathrm{P} 5 \mathrm{~N}$ activity results in the accumulation of pyrimidine nucleotides in erythrocytes in clinical studies 5 and in rabbits treated with lead. ${ }^{6}$ There are few reports concerning P5N activity on workers with occupational exposure to lead..$^{7}$

\section{Methods}

MANUFACTURING PROCESS

Grids (the metallic lead lattices used in making battery plates) are manufactured with automatic casting machines. The grids are then pasted with lead oxide by machine. After drying, the pasted grids (plates) are converted electrically to lead peroxide and lead (plate forming process). Pairs of plates are separated and then cleaned by a brushing machine to get rid of excess metal and paste (plate finishing process). The finished plates are stacked to form battery elements, alternating negative and positive plates with an inert separator between each plate, and welded to form groups (cells) by machine. Cell connectors and battery terminals, cast from lead, are manually gas welded to the cells to complete the batteries (assembling process).

\section{SUBJECTS}

Of the 85 workers in the plant, we selected 72 who had been exposed to lead for at least three months. Six of these were absent on the day of examination and thus could not be included in the study population, leaving 66 lead workers for examination.

As controls, we examined all 26 clerical workers from one section in another plant. None of them had any history of exposure to lead.

Heparinised venous blood samples and spot urine samples were collected from both groups. 
Table 1 Environmental and biological variables in the exposed and non-exposed groups

\begin{tabular}{|c|c|c|c|c|c|c|}
\hline & $\begin{array}{l}\text { Casting and } \\
\text { pasting } \\
(n=5)\end{array}$ & $\begin{array}{l}\text { Plate forming } \\
\text { and finishing } \\
(n=17)\end{array}$ & $\begin{array}{l}\text { Assembling } \\
(n=22)\end{array}$ & $\begin{array}{l}\text { Otherst } \\
(n=22)\end{array}$ & $\begin{array}{l}\text { Exposed } \\
\text { group all } \\
(n=66)\end{array}$ & $\begin{array}{l}\text { Non-exposed } \\
(n=26)\end{array}$ \\
\hline \multirow{6}{*}{$\begin{array}{l}\text { Age } \\
\left.\text { PbA (mg/m }{ }^{3}\right): \\
\text { Range } \\
\text { Air samples (n) } \\
\text { PbB ( } \mu \mathrm{g} / \mathrm{dl}) \\
\mathrm{Hb}(\mathrm{g} / \mathrm{dl}) \\
\text { FEP }(\mu \mathrm{g} / \mathrm{dl}) \\
\text { ALAD }(\mu \mathrm{mol} \\
\text { PBG/h/ml RBC) } \\
\text { P5N }(\mu \mathrm{mol} \\
\text { uridine/h/g Hb) } \\
\text { ALAU (mg/l) } \\
\text { CPU ( } \mu \mathrm{g} / \mathrm{l}) \\
\text { Duration (y) }\end{array}$} & $\begin{array}{l}39(7) \\
0.083(0.04)\end{array}$ & $\begin{array}{l}44(7)^{\star} \\
0 \cdot 17(0 \cdot 19)\end{array}$ & $\begin{array}{l}39(10) \\
0.145(0 \cdot 149)\end{array}$ & $39(9)$ & $40(9)^{\star}$ & $32(12)$ \\
\hline & $0.04-0.154(6)$ & $0.012-0.468(5)$ & $0.015-0.411(7)$ & - & - & - \\
\hline & $\begin{array}{l}40 \cdot 6(8 \cdot 8)^{\star} \\
14 \cdot 3(1 \cdot 1) \\
36 \cdot 2(18 \cdot 9)\end{array}$ & $\begin{array}{l}49 \cdot 2(17 \cdot 4)^{\star} \\
14 \cdot 1(1 \cdot 3) \\
69 \cdot 4(48 \cdot 1)\end{array}$ & $\begin{array}{l}47 \cdot 2(11 \cdot 6)^{\star} \\
14 \cdot 0(1 \cdot 6) \\
73 \cdot 1(38 \cdot 5)^{\star}\end{array}$ & $\begin{array}{l}42 \cdot 6(18 \cdot 7)^{\star} \\
14 \cdot 3(1 \cdot 9) \\
73 \cdot 8(60 \cdot 3)\end{array}$ & $\begin{array}{l}45 \cdot 7(15 \cdot 7)^{\star} \\
14 \cdot 2(1 \cdot 6) \\
69 \cdot 6(48 \cdot 4)^{\star}\end{array}$ & $\begin{array}{l}10 \cdot 8(4 \cdot 4) \\
14 \cdot 6(1 \cdot 5) \\
33 \cdot 1(12 \cdot 3)\end{array}$ \\
\hline & $0.348(0.128)^{\star}$ & $0.315(0.147)^{\star}$ & $0.309(0.128)^{\star}$ & $0.359(0.164)^{\star}$ & $0.330(0.143)^{\star}$ & $1.268(0.329)$ \\
\hline & $10.08(0.46)^{\star}$ & $10.13(2.71)^{\star}$ & $10 \cdot 44(2 \cdot 10)^{\star}$ & $11.69(2.65)^{\star}$ & $10.75(2.44)^{\star}$ & $15 \cdot 34(1.90)$ \\
\hline & $\begin{array}{c}2 \cdot 8(0 \cdot 4) \\
63 \cdot 6(63 \cdot 3) \\
4 \cdot 1(5 \cdot 5)\end{array}$ & $\begin{array}{c}5 \cdot 6(4 \cdot 2) \\
74 \cdot 7(105 \cdot 5) \\
6 \cdot 1(5 \cdot 1)\end{array}$ & $\begin{array}{c}3 \cdot 7(2 \cdot 9) \\
72 \cdot 3(68 \cdot 0) \\
8 \cdot 3(5 \cdot 3)\end{array}$ & $\begin{array}{c}2.9(1.5) \\
74.6(83.0) \\
2.9(3.5)\end{array}$ & $\begin{array}{c}3.9(3.0) \\
73.0(81.5)^{\star} \\
5.6(5 \cdot 2)\end{array}$ & $\begin{array}{c}3 \cdot 6(0.9) \\
36 \cdot 8(60 \cdot 0) \\
-\end{array}$ \\
\hline
\end{tabular}

$\star P<0.05$, (no significant differences were found among the four exposed subgroups.) Values are mean (SD).

†Maintenance service workers, mechanics, and other unclassified workers.

ENVIRONMENTAL MONITORING

For personal breathing zone air samples, a trained technician selected 14 workers whose exposures were thought to be representative in each job category. At the same time, a total of four area samples were collected to obtain general background information near the main operation site in each production section. The air samples were collected on cellulose ester membrane filters $(0.8 \mu \mathrm{m}$ pore size, $37 \mathrm{~mm}$ diameter) with personal air samplers. Before use, each sampling system was calibrated to obtain a flow rate of 21 a minute. Sampling was carried out for six hours excluding breaks. The Institute of Industrial Medicine, Soonchunhyang University, authorised industrial hygiene laboratory for the Korean industries that use lead analysed air lead ( $\mathrm{PbA})$ samples. This laboratory has participated in a national quality control programme, ${ }^{9}$ applied to all Korean industrial hygiene laboratories. In this programme, the Industrial Health Research Institute of the Korean Industrial Safety Corporation was designated as the reference laboratory by the Korean government. This reference laboratory has participated in the American Industrial Hygiene Association proficiency analytical testing programme and has performed internal quality control programmes. The concentration of $\mathrm{PbA}$ was measured by flame atomic absorption spectrophotometry with the National Institute for Occupational Safety and Health (NIOSH) method 7082. ${ }^{10}$ Four field blanks were included and analysis of air samples was corrected by field blanks. Spiked samples $(n=15)$ were prepared by spiking known amounts of lead on cellulose ester membrane filters. ${ }^{10}$ Recovery rates of the spiked samples ranged from $90 \%$ to $99 \%$ (mean; $94 \%$ ). The pooled coefficient of variation calculated for these measurements was $4 \%$.

\section{BIOLOGICAL MONITORING}

Activity of P5N was determined by the method of Tomokuni and Ichiba ${ }^{11}$ with high performance liquid chromatography (HPLC, model LC-5A, Shimadzu, Kyoto, Japan). Nucleotides were extracted from the whole blood as follows: whole blood $(1 \mathrm{ml})$ was deproteinised by adding $2 \mathrm{ml}$ of $0.6 \mathrm{~N} \mathrm{HClO}_{4}$ and centrifuged at $1200 \mathrm{~g}$ for five minutes. The supernatant $(2 \mathrm{ml})$ was neutralised with $2 \mathrm{ml}$ of $0.2 \mathrm{M} \mathrm{K}_{2} \mathrm{CO}_{3}$. Nucleotides were separated with HPLC by linear gradient elution with a low concentration eluent of $0.007 \mathrm{M}$ $\mathrm{KH}_{2} \mathrm{PO}_{4}$ at $\mathrm{pH} 3.90$ and a high concentration eluent of $0.25 \mathrm{M} \mathrm{KH}_{2} \mathrm{PO}_{4}$ and $0.50 \mathrm{M} \mathrm{KCl}$ at pH 4.50.5 Nucleotide standards were purchased from Sigma Chemical Company, USA.

Activity of erythrocyte $\delta$-aminolevulinic acid dehydratase (ALAD) was measured with the method of Haas et al. ${ }^{12}$ Lead concentration in whole blood $(\mathrm{PbB})$ was analysed with flameless atomic absorption spectrophotometry. ${ }^{13}$ The accuracy was checked by inclusion of a whole blood reference sample (BCR No 196, Community Bureau of Reference, CEC, Belgium) in the sample series. Free erythrocyte protoporphyrin (FEP) was determined with the method of Piomelli. ${ }^{14}$ Urinary coproporphyrin (CPU) was measured with the fluorometric HPLC method of Tomokuni and Hirai. ${ }^{15}$ Urinary $\delta$-aminolevulinic acid (ALAU) was determined with the colorimetric method of Tomokuni and Ogata, ${ }^{16}$ after a threefold dilution with distilled water. Packed cell volume was measured by the capillary method, and haemoglobin $(\mathrm{Hb})$ concentration by the cyanmethaemoglobin method. All urine analyses were done on spot samples, and the data were corrected to a specific gravity of 1.024 .

\section{STATISTICAL ANALYSES}

The significance of the difference in the variables between the exposed group as a whole and the non-exposed group was tested by $t$ tests. Among five groups (four exposed subgroups and one non-exposed group) significance was tested by a one way analysis of variance (ANOVA). If the ANOVA showed significance at $P<0.05$, Scheffe's multiple comparison test was used to identify which subgroup or group was significantly different from which other subgroups or groups. Relations between PbB or P5N and other biological variables were evaluated with Pearson's correlation coefficients. 


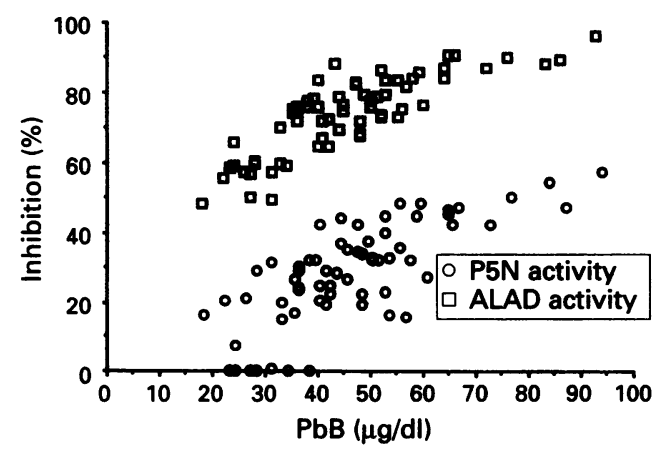

Relation between the inhibition of P5N or ALAD activity and blood lead concentration in 66 battery workers.

\section{Results}

LEAD EXPOSURE IN THE LEAD-ACID BATTERY FACTORY

Table 1 shows the concentrations of biological variables in the exposed and non-exposed groups. The difference in $\mathrm{PbB}$ between the four exposed subgroups and the non-exposed group was significant. There were no significant differences in mean $\mathrm{PbB}$ among the four exposed subgroups. $\mathrm{PbB}$ in 39 (59\%) of the 66 exposed workers exceeded $40 \mu \mathrm{g} / \mathrm{dl}$, the upper limit recommended by the World Health Organisation for adult male workers. ${ }^{17}$ In nine $(14 \%)$ of the exposed workers $\mathrm{PbB}$ was above $60 \mu \mathrm{g} / \mathrm{dl}$.

Table 1 also summarises the $\mathrm{PbA}$ concentrations at the lead-acid battery factory. In this survey, $13(72 \%)$ of 18 air samples for lead exceeded the United States time weighted average permissible exposure limit of 0.05 (range $0.012-0.468) \mathrm{mg} / \mathrm{m}^{3}$. All of the mean $\mathrm{PbA}$ values in the three processes were above the permissible exposure limit. A highest mean concentration of $\mathrm{PbA}$ and $\mathrm{PbB}$ were found in the section where plate forming and finishing were done.

Compared with the non-exposed group, FEP in the exposed groups was significantly increased, whereas P5N and ALAD activity were significantly inhibited. The difference in $\mathrm{Hb}$ and ALAU between the exposed and nonexposed groups was insignificant. Mean CPU was higher in the exposed than in the nonexposed group.

RELATION BETWEEN PbB AND P5N ACTIVITY OR OTHER BIOLOGICAL VARIABLES

In 66 battery workers, the correlation coefficients between $\mathrm{PbB}$ and $\mathrm{ALAD}, \mathrm{P} 5 \mathrm{~N}, \mathrm{ALAU}$, FEP, CPU, packed cell volume, and $\mathrm{Hb}$ were $-0.826 \quad(P<0.001),-0.735 \quad(P<0.001)$, $0.648(P<0.001), 0.584(P<0.001), 0.501$ $(P<0.001), 0.232 \quad(P>0.05)$, and 0.176 $(P>0.05)$, respectively. The correlation coefficients between P5N and ALAD, log ALAU, $\log$ FEP, CPU, packed cell volume, and $\mathrm{Hb}$ were $0.729(P<0.001),-0.531(P<0.001)$, $-0.481(P<0.001),-0.420(P<0.001)$, $-0.235(P>0.05)$, and $-0.185(P>0.05)$, respectively.

We compared the degree to which lead inhibited P5N and ALAD activity (figure).
Table 2 Correlation coefficients between nucleotide concentration and $P 5 N$ or $P b B$ in 28 lead workers

\begin{tabular}{llc}
\hline Nucleotide & \multicolumn{1}{l}{ P5N } & $P b B$ \\
\hline AMP & -0.051 & 0.062 \\
UDPG & $-0.656^{\star}$ & $0.678^{\star}$ \\
NADP & -0.242 & 0.251 \\
UDP & -0.034 & -0.190 \\
CDP & -0.320 & 0.079 \\
ADP & -0.080 & 0.185 \\
GDP & 0.315 & -0.104 \\
UTP & 0.114 & 0.015 \\
CTP & $-0.421^{\star}$ & $0.403^{\star}$ \\
ATP & 0.281 & 0.088 \\
GTP & 0.153 & 0.001
\end{tabular}

$\star \mathrm{P}<0.05$. AMP, adenosine $5^{\prime}$-monophosphate; UDPG, uridine 5'-diphosphate-glucose; NADP, nicotinamide adenine dinucleotide phosphate; UDP, uridine 5 -diphosphate; CDP dinucleotide phosphate; UDP, uridine 5'-diphosphate; CDP, cytidine 5'-diphosphate; ADP, adenosine 5'-diphosphate;
GDP, guanosine 5'-diphosphate; UTP, uridine 5'-triphosGDP, guanosine 5'-diphosphate; UTP, uridine 5'-triphos-
phate; CTP, cytidine 5'-triphosphate; ATP, adenosine 5'triphosphate; GTP, guanosine 5'-triphosphate.

The percentage of inhibition of $\mathrm{P} 5 \mathrm{~N}$ and ALAD activity was calculated with the mean value of the non-exposed group as a base. In specimens in which P5N activity was higher than the mean value of the non-exposed group, enzyme inhibition was treated as $0 \%$. The $\mathrm{PbB}$ dose-response curves for ALAD and P5N showed similar patterns. The inhibitory effect of lead exposure was higher on ALAD than on $\mathrm{P} 5 \mathrm{~N}$ over the whole range of $\mathrm{PbB}$ concentrations. At $18 \mu \mathrm{g} / \mathrm{dl}$ of $\mathrm{PbB}, 48 \%$ of ALAD activity was inhibited, and most of the activity was inhibited above $40-50 \mu \mathrm{g} / \mathrm{dl}$. These findings show that ALAD activity is quite sensitive to lead exposure. ${ }^{18}$

Table 2 shows the relation between the concentration of erythrocyte nucleotides and $\mathrm{P} 5 \mathrm{~N}$ activity or $\mathrm{PbB}$. The amount of uridine 5'-diphosphate-glucose (UDPG) correlated positively with $\mathrm{PbB}$ and inversely with erythrocyte P5N activity. Similar results were obtained for the cytidine 5'-triphosphate analysis.

\section{Discussion}

Few studies of lead-acid battery workers in developing countries have been reported in recent years. Although our study has some limitations as a small scale, cross sectional study, our survey showed a high prevalence of increased concentrations of $\mathrm{PbB}$ of battery workers in Korea. Concentrations of $\mathrm{PbB}$ in the battery workers in this study were found to be higher than those in workers at a large United States battery manufacturer, where only $6 \%$ of $\mathrm{PbB}$ concentrations exceeded $60 \mu \mathrm{g} / \mathrm{dl}^{19}$ But they were lower than those found in Jamaican battery manufacturers, where $28 \%$ of the workers exceeded $60 \mu \mathrm{g} / \mathrm{dl},{ }^{2}$ and those found at a battery factory in Sudan, where $95 \%$ of the workers had $\mathrm{PbB}$ concentrations above $40 \mu \mathrm{g} / \mathrm{dl}^{3}{ }^{3}$ In battery manufacture, lead dust or fume from manual work in the process of casting and pasting, and also in the process of assembling, is the major source of exposure. ${ }^{20}$ The high $\mathrm{PbB}$ concentration (80.7 (14.7) $\mu \mathrm{g} / \mathrm{dl})$ of casting and pasting workers in Sudan, and the higher $\mathrm{PbA}$ concentration in the process of assembling in Jamaica, suggest that different battery production technologies (machine or manual) 
contribute to the differences in $\mathrm{PbB}$ concentrations in Korea, Sudan, and Jamaica. ${ }^{23}$ The low $\mathrm{PbB}$ concentrations in lead-acid battery workers in the United States is most likely related to application of more automated production procedures, greater use of engineering control of lead exposures, more comprehensive application of environmental and personal monitoring, and greater regulatory attention to this problem.

A comparison of the rather high $\mathrm{PbA}$ concentrations measured in the Korean factory with those reported in other published surveys $^{231921}$ indicates that high and low exposure processes in battery manufacture may vary with the factory. No significant differences were found between the four sections in biological indices such as $\mathrm{PbB}, \mathrm{FEP}, \mathrm{P} 5 \mathrm{~N}$, and ALAD. These findings show that the workers in the factory were exposed to similarly high concentrations of lead regardless of the section in which they worked. The workers may move about the plant and thereby receive bystander exposure from adjacent processes conducted in the same building that did not have adequate, separate ventilation systems for each process.

P5N was first reported by Valetine et al in 1974 in their description of haemolytic anaemia. ${ }^{22}$ The enzyme in red cell cytosol catalyses the hydrolytic dephosphorylation of pyrimidine 5 '-monophosphates but is ineffective on purine nucleotides. The reaction is thought to be a necessary step in the degradation of ribosomal RNA in maturing red cells. Through this mechanism, the erythrocyte is able to diffuse pyrimidine nucleotides as soluble nucleosides and retain purine nucleotides as a source of ATP. The accumulated pyrimidine nucleotides in red cells are thought to shorten the cells' life span in lead poisoning, ${ }^{23}$ although details remain unknown. Activity of P5N is inhibited by lead, and it is considered an indicator of lead exposure. ${ }^{4}{ }^{24}$ In our study the mean (SD) erythrocyte P5N activity of 26 normal subjects was $15.34(1.9) \mu \mathrm{mol}$ uridine $/ \mathrm{h} / \mathrm{g} \mathrm{Hb}$, similar to the $16 \cdot 2(2 \cdot 5) \mu \mathrm{mol}$ uridine/h/g Hb reported by Sakai et al. ${ }^{25}$ The validity of P5N activity was also estimated by the method of Zielhuis and Verberk. ${ }^{26}$ If the lower limit for normal P5N activity is 11.54 $\mu \mathrm{mol}$ uridine/h/g Hb ( $-2 \mathrm{SD})$, then the sensitivity is $88 \%$, as 37 out of 42 subjects with $\mathrm{PbB} \geqslant 40 \mu \mathrm{g} / \mathrm{dl}$ were below it. The specificity of $\mathrm{P} 5 \mathrm{~N}$ is $82 \%$, as 41 out of 50 subjects with $\mathrm{PbB}<40 \mu \mathrm{g} / \mathrm{dl}$ were above it. Validity (sensitivity + specificity) is $1 \cdot 70$. These results are comparable to the findings of Tomokuni et $a l,{ }^{27}$ where sensitivity was $73 \%$ and specificity was $93 \%$. In our study the erythrocyte P5N activity was found to be a valid biological correlate with $\mathrm{PbB}$, although further study is indicated to determine its sensitivity and specificity in a large population. Activity of P5N also correlated highly with other biological variables such as ALAD activity, which we found to be a more sensitive indicator of lead exposure than P5N activity (figure). The erythrocyte ALAD activity test has one disadvantage: it must be carried out immediately after blood sampling because this enzyme is vulnerable and inactivated during storage. By contrast, erythrocyte $\mathrm{P} 5 \mathrm{~N}$ is stable for at least seven days in blood stored at $4^{\circ} \mathrm{C} .{ }^{28}$ As the assay of $\mathrm{P} 5 \mathrm{~N}$ can be carried out with stored samples, erythrocyte $\mathrm{P} 5 \mathrm{~N}$ activity seems to be more suitable than erythrocyte ALAD activity for screening lead exposure. Our results also showed that erythrocyte UDPG and CTP concentration correlated positively with $\mathrm{PbB}$ and inversely with P5N activity. Thus, the depression of erythrocyte P5N activity by lead exposure results in the accumulation of erythrocyte pyrimidine nucleotides such as UDPG and CTP. Although the role of these accumulated pyrimidine nucleotides in the red cells of the battery workers remains sketchy, our study shows that lead has a definite effect on nucleotide metabolism.

In general, the standard analysis of $\mathrm{PbB}$ performed in laboratories around the world remains the most useful index of recent exposure. ${ }^{29}$ Our results indicated that the erythrocyte P5N activity test provides supporting evidence of lead exposure and shows the effect of lead on nucleotide metabolism.

1 Hernberg S, Dodson VN, Zenz C. Lead and its compounds. In: Zenz C, eds. Occupational medicine, 2nd ed. Chicago: Yearbook Medical Publishers, 1988:547-82.

2 Matte TD, Figueroa JP, Burr G, Flesch JP, Kleenlyside RA, Baker EL. Lead exposure among lead-acid battery workers in Jamaica. Am $\mathcal{F}$ Ind Med 1989;16:167-77.

3 Awad el Karim MA, Hamed AS, Elhaimi YAA, Osman Y. Effects of exposure to lead among lead-acid battery factory workers in Sudan. Arch Environ Health 1986; 41:261-5.

4 Paglia DE, Valentine WN, Fink K. Lead poisoning. $f$ Clin Invest 1977;60:1362-6.

5 Angle CR, McIntire MS, Swanson MS, Stohs SJ Erythrocyte nucleotides in children-increased blood lead and cytidine triphosphate. Pediatr Res 1982;16: 331-4.

6 Swanson MS, Angle CR, Stohs SJ, Rovang KS. Erythrocyte nucleotides from control and lead-treated rabbits. Res Commun Chem Pathol Pharmacol 1980;27 353-61.

7 Sakai T, Ushio K. A simplified method for determining erythrocyte pyrimidine $5^{\prime}$-nucleotidase (P5N) activity by Ind Med 1986;43:839-44.

8 Ichiba M, Tomokuni K. Studies on erythrocyte pyrimidine 5 -nucleotidase (P5N) test and its evaluation in workers occupationally exposed to lead. Int Arch Occup Environ Health 1990;62:305-10.

9 Korean Ministry of Labor. Regulation on quality control for measurement of industrial environment. Seoul, Korea: Korean Ministry of Labor, 1992. (Announcement No 92-18.)

10 National Institute for Occupational Safety and Health. NIOSH Manual of Analytical Methods, 3rd ed. Cincinnati: NIOSH, 1984.

11 Tomokuni K, Ichiba M. Simple determination of erythrocyte pyrimidine $5^{\prime}$-nucleotidase activity in human blood by high-performance liquid chromatography. Ind Health 1986;24:227-33.

12 Haas TH, Mache W, Schaller KH, Mache K, Klavis G, Stumpf $R$. The determination of delta-amino-laevulinic acid dehydratase activity and its diagnostic value Internationales Archives fur Arbeitsmedzin 1972;30 87-104.

13 Subramanian KS, Meranger JC. A rapid electrothermal atomic absorption spectrophotometric method for cadmium and lead in human whole blood. Clin Chem 1981;27:1866-71

14 Piomelli S. A micromethod for erythrocyte porphyrins. f Lab Clin Med 1973;81:932-40.

15 Tomokuni K, Hirai Y. Simple liquid-chromatographic determination of urinary coproporphyrin in workers exposed to lead. Clin Chem 1986;32:872-3.

16 Tomokuni K, Ogata M. Simple method for determination of urinary $\delta$-aminolevulinic acid as an index of lead exposure. Clin Chem 1972;18:1534-6.

17 World Health Organization. Report of a study group: recommended health-based limits in occupational exposure to heavy metals. Geneva: WHO, 1980. (Technical Reports Series 647.)

18 Meredith PA, Moore MR, Goldberg A. Erythrocyte $\delta$-aminolevulinic acid dehydratase activity and blood 
protoporphyrin concentrations as indices of lead exposure and altered haem biosynthesis. Clin Sci 1979; 56:61-9.

19 Gartside PS, Buncher CR, Lerner S. Relationship of air lead and blood lead for workers at an automobile battery factory. Int Arch Occup Environ Health 1982;50:1-10.

20 Burgess WA. Recognition of health hazards in industry. $A$ review of materials and processes. New York: John Wiley, 1981:164-70.

21 Williams $M K$, King E, Walford J. An investigation of lead absorption in an electric accumulator factory with the use of personal samplers. $B r \mathcal{F}$ Ind Med 1969; 26:202-16.

22 Valentine WN, Fink K, Paglia DE, Harris SR, Adams WS. Hereditary hemolytic anemia with human erythrocyte pyrimidine 5'-nucleotidase deficiency. $\mathcal{F}$ Clin Invest 1974; 54:866-79.

23 Valentine WN, Paglia DE, Fink K, Maldokoro G. Lead poisoning. Association with hemolytic anemia, basopoisoning. Association with hemolytic anemia, baso-
philic stippling, erythrocyte pyrimidine $5^{\prime}$-nucleotidase philic stippling, erythrocyte pyrimidine 5 -nucleotidase idines. $\mathcal{F}$ Clin Invest 1976;58:926-32.
24 Mohammed-Brahim B, Buchet JP, Lauwerys $R$. Erythrocyte pyrimidine 5 '-nucleotidase activity in workers exposed to lead mercury or cadmium. Int Arch Occup Environ Health 1985;55:247-52.

25 Sakai T, Araki T, Ushio K. Determination of pyrimidine 5 -nucleotidase (P5N) activity in whole blood as index of lead exposure. Br f Ind Med 1988;45:420-5.

26 Zielhuis RI. Verberk MM. Validity of biological tests in epidemiological toxicology. Internationales Archives fur epidemiological toxicology. In

27 Tomokuni K, Ichiba M, Hirai Y, Hasegawa T, Sugimoto K. Relationship between inhibition of erythrocyte pyrimidine 5 -nucleotidase activity and biological response for porphyrin metabolism in workers occupationally exposed to lead. Int Arch Occup Environ Health 1988; 60:431-6.

28 Torrance J, West C, Beutler E. A simple rapid radiometric assay for pyrimidine-5'-nucleotidase. 7 Lab Clin Med 1977;90:563-8.

29 Braithwaite RA, Brown SS. Clinical and sub-clinical lead poisoning: a laboratory perspective. Hum Toxicol 1988;7: poisonin. 